\title{
Higher Order Thinking Skills (HOTS) Profiles Students on the Material of Three Variable Linear Equation Systems
}

\author{
Yenny Suzanna*, Faisal, Srimuliati, Iyana Maulida \\ IAIN Langsa \\ Kota Langsa, Indonesia \\ *yenni@iainlangsa.ac.id, faisal@iainlangsa.ac.id, srimuliati@iainlangsa.ac.id, iyanamaulida3@gmail.comline
}

\begin{abstract}
Higher order thinking skills (HOTS) of students in the era of the Industrial Revolution 4.0 are a priority. The research objective was to determine the HOTS profile of students in solving math problems on the material of three-variable linear equations. The research was conducted using qualitative methods. The subject consisted of three students each having high, medium, and low abilities. The instrument used was a test of mathematical problem solving, three-variable linear equations, and an interview sheet. The results showed that students with high and moderate abilities can use three HOTS indicators in solving math problems. Students with low proficiency can only use one HOTS indicator. Thus the three research subjects have higher order thinking skills (HOTS) but with different levels of indicators.
\end{abstract}

Keywords-Higher Level Thinking Skills (HOTS), problem solving, Three Variable Linear Equation System (SPLTV), high school students

\section{INTRODUCTION}

Higher order thinking has recently been discussed by education experts and also by education supervisors in the face of the 4.0 industrial revolution. External challenges are related to the 4.0 industrial revolution which collaborates cyber technology and automation technology, various issues of technological and information progress, the rise of the creative industry, the development of education at the international level. This phenomenon illustrates the need for strong resources in order to compete and coexist, therefore higher order thinking skills are needed. Mathematics is a universal language so that the math abilities of students in one country can be compared with other countries. In addition, mathematics is also used as a measuring tool to determine the progress of education in a country [1]. For example, PISA (Program for International Student Assessment) and TIMSS (The International Mathematics and Science Survey) conduct international bench marking regularly to measure and compare progress of mathematics education in several countries. PISA focuses on assessing students' mathematical performance in their ability to solve math problems in everyday life. [2]. While
TIMSS can provide information about factors that affect student achievement such as student background, student attitudes towards subjects, teachers and class characteristics [3].

In addition, higher order thinking skills are a measure or community view of schools. The majority of people think that choosing a good school will determine the success of their children in the future. So that many parents try to enroll their children to their favourite high school, because the majority of people assume that by entering their child to the favourite high school they can provide the best education in forming higherorder knowledge and thinking skills.

Many studies that have been conducted show that students in Indonesia have a low HOTS ability compared to other countries. One of the contributing factors is that students are less trained so that students do not understand the material being studied well. High-order thinking for students needs to be trained by providing problem solving problems [4]. By getting students used to working on challenging and interesting questions it will grow higher order thinking skills in students. According to Alice Thomas and Glenda's opinion that higher order thinking skills are an achievement of the ability to think towards higher order of thinking [5]. The above opinion shows that higher-order thinking is the individual's ability to solve complex problems, namely problems that require a higher level of thinking. higher. Problem solving is widely used to measure or develop HOTS. Teachers are generally required to make mathematical questions that develop HOTS. Anderson and Krathwohl stated that the HOTS category is analysing, evaluating, and creating [6].

Previous reference studies regarding higher order thinking skills are usually related to increasing higher order thinking skills (HOTS) through the application of certain learning models in improving students' thinking skills [7]. Some references discuss the development of teaching materials to improve students' higher order thinking [8]. However, this study discusses the high-order thinking profile of high school students on the material of three-variable linear equations. This research was conducted at favorite high school. The purpose of 
this study was to analyze the high order thinking skills of students in favorite high school.

\section{RESEARCH METHODS}

This study used a qualitative method. Qualitative research methods are examining the condition of natural objects, where the researcher is the key instrument. The data collection technique was carried out by using triangulation [9] .This research design used a descriptive research design that describes in general the facts found. Descriptive research design also explained and describes existing phenomena or circumstances. The research approach was a case study according to Creswell, a case study is a technique to understand an individual which was carried out integratively and comprehensively in order to obtain a deep understanding of the individual [10].

The case study here is an exploration in exploring and gathering detailed and in-depth information on a phenomenon that is oriented towards higher level thinking skills of high school students. The results of gathering information obtained from what the subject experienced regarding higher order thinking skills were then analyzed and then described in words that were easy to understand. This study involved three students who had studied the material of the three-variable linear equation system (SPLTV) with different mathematical abilities, namely high, medium and low abilities.

The data collection technique was done by giving tests and interviews. The research instrument was the researchers themselves, test questions for higher-order thinking skills in the form of material description of the three-variable linear equation system (SPLTV), as well as interview guidelines. The use of humans or researchers as research instruments is based on the belief that only humans are able to assess the meaning of an event or various social interactions [11]. The test was conducted to determine students' higher order thinking skills in solving SPLTV questions. Interviews were conducted using a voice recorder or audio recorder to obtain additional information that has not been described or seen in the written test. Data processing was carried out by data triangulation process, namely by analysing the suitability or consistency of the HOTS questions criteria with interviews.

\section{RESULTS AND DISCUSSION}

\section{A. Results}

Data exposure of students' higher level thinking skills in solving three-variable linear equation problems was carried out by providing labelling and coding of research data. The following is the explanation, triangulation, and description of the research data:

1) Labeling and coding of research data: There are two types of data, namely the students' higher order thinking test results (HOTS) and interview data on each research subject. The data was obtained through two stages including giving
HOTS 1 and HOTS 2, then interviewing after the students completed HOTS. The interview data were then transcribed and given the $\mathrm{P}$ label as researcher. Labels for research subjects have six digits, namely the first two digits state the subject based on ability, the third and fourth digits state HOTS 1 or HOTS 2, the last two digits state the sequence of interview activities. The use of labels in this study is explained as follows:

- The first two digits indicate the research subject based on ability. ST for high-ability subjects, SS for mediumcapable subjects, and SR for low-ability subjects.

- The third and fourth digits represent the student's highlevel proficiency test. T1 for HOTS 1 and T2 for HOTS 2 .

- The last two digits indicate the sequence of interview activities.

For example: STT101 means that high-ability subjects are given HOTS 1 in the first order in the interview transcript, SRT203 means that low-ability subjects are given HOTS 2 in third place in the interview transcript

The following is the coding of higher-order thinking skills in table 1:

TABLE I. CODING AND INDICATORS OF HIGHER-ORDER THINKING SKILLS ON THE MATERIAL OF THREE VARIABLE LINEAR EQUATION SYSTEMS (SPLTV)

\begin{tabular}{|c|c|c|}
\hline $\begin{array}{c}\text { Higher Order } \\
\text { Thinkings Skills } \\
\text { (HOTS) }\end{array}$ & Indicator & Code \\
\hline Analytical skills & $\begin{array}{l}\text { 1. Analyzing the information } \\
\text { on the questions, namely } \\
\text { knowing or being able to } \\
\text { formulate the problems } \\
\text { (questions) contained in the } \\
\text { questions. } \\
\text { 2. Comparing the value } \\
\text { between one variable and } \\
\text { another variable }\end{array}$ & $\begin{array}{l}\text { KA1 } \\
\text { KA2 }\end{array}$ \\
\hline Evaluation ability & $\begin{array}{l}\text { 1. Designing and making } \\
\text { decisions using a method or } \\
\text { method that is suitable for } \\
\text { solving problems. } \\
\text { 2. Testing the truth of the } \\
\text { results that have been } \\
\text { obtained. }\end{array}$ & $\begin{array}{l}\text { KE1 } \\
\text { KE2 }\end{array}$ \\
\hline Creation ability & $\begin{array}{l}\text { Solve problems in more than } \\
\text { one way or method }\end{array}$ & KK \\
\hline $\begin{array}{l}\text { Logic and reasoning } \\
\text { skills }\end{array}$ & $\begin{array}{l}\text { Make conclusions from the } \\
\text { results that have been } \\
\text { obtained }\end{array}$ & KLP \\
\hline
\end{tabular}

2) Exposure, validation, and conclusions of research data on students' higher order thinking skill based on ability levels: Data exposure, validation, presentation and drawing conclusions on highly skilled subjects (ST) in solving problem item number 1 . 


\section{ST data exposure on HOTS questions and interviews}

Based on the test result data and the ST interview transcript on question number 1 for HOTS 1, it can be described that ST knows or is able to formulate the questions contained in the questions into a mathematical model in table form, then ST is able to change the problem of question 1 made into several equations (STT103, STT105). Then ST can make decisions in solving problems using the mixed method (STT107). Furthermore, ST tests the truth of the results obtained by substituting the values obtained into known equations (STT107). ST can conclude the results obtained (STT107) and can compare the values of variables a, b and c (STT107). However, ST does not use other methods in solving problems. ST only uses mixed methods in solving the problem even though ST knows there are other ways that can be used to solve the problem (STT110).

More clearly, data on ST' high-order thinking skills (HOTS) in solving question number 1 is recapitulated in Table 2 below.

TABLE II. HIGH-ORDER THINKING SKILLS (HOTS) IN SOLVING QUESTION NUMBER 1

\begin{tabular}{|l|l|}
\hline $\begin{array}{c}\text { Indicator } \\
\text { Codes }\end{array}$ & \multicolumn{1}{|c|}{ Abilities used } \\
\hline KA1 & $\begin{array}{l}\text { Analyze information by making mathematical models } \\
\text { into tables and in the form of several equations } \\
\text { (STT103, STT105) }\end{array}$ \\
\hline KE1 & $\begin{array}{l}\text { Designing and making decisions using mixed methods } \\
\text { namely elimination-substitution (STT107) }\end{array}$ \\
\hline KE2 & $\begin{array}{l}\text { Test the correctness of the results obtained by } \\
\text { substituting the values obtained into known equations } \\
\text { (STT107) }\end{array}$ \\
\hline KLP & Making conclusions from the results obtained (STT107) \\
\hline KA2 & Comparing the values between variables (STT107) \\
\hline
\end{tabular}

3) Data exposure, validation, presentation and conclusion of highly skilled subjects (ST) in solving problem item number 1 on the HOTS 2 test: Based on the data from the test results and the transcript of the ST interview on question number 1 for HOTS 2, it can be described that ST knows and can formulate problems into a mathematical model in tabular form and is continued by making several equations (STT203, STT205). Then ST took the decision to solve the problem using the mixed method, mixing the elimination method and the substitution method (STT209, STT211). Then ST tests the correctness of the answers obtained by substituting the values obtained into the equations. (STT212). The next step ST makes conclusions from the results obtained (STT212) and compares the values between variables (STT212). ST does not use other methods to solve the problem, even though ST knows that there are other methods that can be used to solve the problem (STT213).

The following is data on ST's higher order thinking skills (HOTS) in solving question number 1 on the HOTS 2 test.
TABLE III. High ORdER THINKING SKILl (HOTS) ST IN PROBLEM SOLVING NUMBER 1 ON THOTS 2

\begin{tabular}{|l|l|}
\hline $\begin{array}{c}\text { Indicator } \\
\text { Codes }\end{array}$ & \multicolumn{1}{|c|}{ Abilities used } \\
\hline KA1 & $\begin{array}{l}\text { Analyze information by making mathematical models } \\
\text { into tabular form and then in several forms of } \\
\text { equations (STT203, STT205) }\end{array}$ \\
\hline KE1 & $\begin{array}{l}\text { Designing and making decisions using mixed } \\
\text { methods, namely elimination-substitution (STT209, } \\
\text { STT211) }\end{array}$ \\
\hline KE2 & $\begin{array}{l}\text { Test the correctness of the results obtained by } \\
\text { substituting the values obtained into known equations } \\
\text { (STT212) }\end{array}$ \\
\hline KLP & Make conclusions from the results obtained (STT212) \\
\hline KA2 & Comparing values between variables (STT212) \\
\hline
\end{tabular}

a) High Order Thinking Skill (HOTS) ST in problem solving number 1 on THOTS 2

TABLE IV. Triangulation Results Data of Data ST in Problem SOLVING NUMBER 1

\begin{tabular}{|l|l|}
\hline $\begin{array}{c}\text { Indicator } \\
\text { Codes }\end{array}$ & \multicolumn{1}{|c|}{ The Convergence Interpretation } \\
\hline KA1 & $\begin{array}{l}\text { Analyzing the information by making mathematical } \\
\text { models into tabular form followed by several } \\
\text { equations }\end{array}$ \\
\hline KE1 & $\begin{array}{l}\text { Designing and making decisions using mixed } \\
\text { methods, namely elimination-substitution }\end{array}$ \\
\hline KE2 & $\begin{array}{l}\text { Test the correctness of the results obtained by } \\
\text { substituting the values obtained into the equations }\end{array}$ \\
\hline KLP & Making conclusions \\
\hline KA2 & Comparing the values between variables \\
\hline
\end{tabular}

b) Concluding of ST data in completing HOTS: Based on the triangulation results, it can be described that ST uses the five indicators of higher-order thinking skills to solve question number 1. On the answer sheet, ST does not write down all the methods he knows, but only one method is used, namely the mixed method. However, during the interview, ST knew that there were other methods that could be used in solving the questions, and ST could reveal the reasons for using the methods used in solving the questions. Based on the results of the written test and interview data, it can be concluded that the high-order thinking skills of ST in solving the Three Variable Linear Equation System (SPLTV) questions in question number 1 are as follows:

- Analyze information by making mathematical models into tabular form (KA1)

- Designing and making decisions using mixed methods namely elimination-substitution (KE1)

- Test the correctness of the results obtained by substituting the values obtained into known equations (KE2)

- Making conclusions from the results obtained (KLP)

- Comparing the values between variables (KA2) 
HOTS ST data analysis solving question number 2 for test 1 is described in Table 5.

TABLE V. HOTS ST COMPLETED PROBLEM NUMBER 2

\begin{tabular}{|l|l|}
\hline \multicolumn{1}{|c|}{$\begin{array}{c}\text { Indicator } \\
\text { Codes }\end{array}$} & \multicolumn{1}{|c|}{ Abilities Used } \\
\hline KA1 & $\begin{array}{l}\text { Analyzing information by making mathematical } \\
\text { models into the form of several equations (STT16) }\end{array}$ \\
\hline KE1 & $\begin{array}{l}\text { Designing and making decisions using mixed } \\
\text { methods, namely elimination-substitution (STT121, } \\
\text { STT122) }\end{array}$ \\
\hline KE2 & $\begin{array}{l}\text { Testing the correctness of the results obtained by } \\
\text { substituting the values obtained into known equations } \\
\text { (STT121) }\end{array}$ \\
\hline KLP & $\begin{array}{l}\text { Making conclusions from the results obtained } \\
\text { (STT121) }\end{array}$ \\
\hline KA2 & Compares the values of all variables (STT121) \\
\hline
\end{tabular}

Furthermore, the ST data description resolves question number 2 on the HOTS 2 test. The following are the results of the written test answers and ST interview excerpts in table 6.

TABLE VI. HOTS ST COMPLETED PROBLEM NUMBER 2

\begin{tabular}{|l|l|}
\hline $\begin{array}{c}\text { Indicator } \\
\text { Codes }\end{array}$ & \multicolumn{1}{|c|}{ Abilities Used } \\
\hline KA1 & $\begin{array}{l}\text { Analyzing information by making mathematical } \\
\text { models into the form of several equations (STT216, } \\
\text { STT217, STT221) }\end{array}$ \\
\hline KE1 & $\begin{array}{l}\text { Designing and making decisions using mixed } \\
\text { methods, namely elimination-substitution (STT218, } \\
\text { STT220, STT222) }\end{array}$ \\
\hline KE2 & $\begin{array}{l}\text { Testing the correctness of the results obtained by } \\
\text { substituting the values obtained into known equations } \\
\text { (STT222) }\end{array}$ \\
\hline KLP & $\begin{array}{l}\text { Making conclusions from the results obtained } \\
\text { (STT222, STT224) }\end{array}$ \\
\hline KA2 & Comparing the values of all variables (STT222) \\
\hline
\end{tabular}

4) Validation and presentation of ST data in completing HOTS: In testing the validity of ST data in solving question number 2 on the HOTS 1 and HOTS 2 tests, data triangulation was carried out on both tests. The triangulation results show that the ST expression tends to be consistent. It was concluded that the ST data in solving questions was valid. The following is the triangulation in table 7 .

TABLE VII. TRiangulation Results of ST Data IN PROBlem SOLVING NUMBER 2

\begin{tabular}{|l|l|}
\hline \multicolumn{1}{|c|}{$\begin{array}{c}\text { Indicator } \\
\text { Codes }\end{array}$} & \multicolumn{1}{|c|}{ The Convergence Interpretation } \\
\hline KA1 & $\begin{array}{l}\text { Analyzing information by making mathematical } \\
\text { models into the form of several equations }\end{array}$ \\
\hline KE1 & $\begin{array}{l}\text { Designing and making decisions using mixed } \\
\text { methods, namely elimination-substitution }\end{array}$ \\
\hline KE2 & $\begin{array}{l}\text { Testing the correctness of the results obtained by } \\
\text { substituting the values obtained into known equations }\end{array}$ \\
\hline KLP & Making conclusions from the results obtained \\
\hline KA2 & Comparing the values of all variables \\
\hline
\end{tabular}

5) Concluding ST data in completing HOTS: Based on the triangulation results, ST uses five indicators of high-order thinking skills in solving question number 2 . On the answer sheet, ST does not use all the methods he knows, but only one method, namely the mixed method. Actually, ST knows that there are other methods that can be applied in solving problems, and ST can also explain the reasons for using the method used in solving the questions. From the results of the tests and interviews it was concluded that the high-order thinking skills of ST in item 2 were as follows:

- Analyzing information by making mathematical models into the form of several equations (KA1)

- Designing and making decisions using mixed methods namely elimination substitution (KE1)

- Testing the correctness of the results obtained by substituting the values obtained into known equations (KE2)

- Making conclusions from the results obtained (KLP)

- Comparing the values of all variables (KA2)

With the same analysis as ST was also carried out on SS and SR. The following is the interpretation of SS convergence on the HOTS 1 and HOTS 2 tests:

6) Validation of HOTS1 and HOTS2 SS in solving problem number 1: Data validity HOTS 1 and HOTS 2 SS solved question number 1 triangulation to see the suitability of the data. Based on the HOTS 1 and HOTS 2 tests, the data from the interviews with SS tends to be consistent. It can be concluded that SS's higher order thinking skill in problem solving item number 1 is said to be valid as in table 8 .

TABLE VIII. TRIANGULATION RESULTS HOTS 1 AND HOTS 2 SS TEST DATA COMPLETE QUESTION NUMBER 1

\begin{tabular}{|l|l|}
\hline $\begin{array}{c}\text { Indicator } \\
\text { Codes }\end{array}$ & \multicolumn{1}{|c|}{ The Convergence Interpretation } \\
\hline KA1 & $\begin{array}{l}\text { Analyzing information by making mathematical } \\
\text { models into the form of several equations }\end{array}$ \\
\hline KE1 & $\begin{array}{l}\text { Designing and making decisions using mixed } \\
\text { methods, namely elimination-substitution }\end{array}$ \\
\hline KE2 & $\begin{array}{l}\text { Testing the correctness of the results obtained by } \\
\text { substituting the values obtained into known equations }\end{array}$ \\
\hline KLP & Making conclusions from the results obtained \\
\hline KA2 & Comparing the values of all variables \\
\hline
\end{tabular}

7) SS data HOTS conclusions in problems solving: The results of the triangulation can be concluded that SS uses three indicators of higher order thinking skills to solve problem number 1. SS only uses one method, namely the mixed method. SS is not sure that he can solve the problem using another method, being used to mixed methods. The SS knows there are other ways to solve the problem. Conclusion on SS in question number 1 : 
- Analysing information by making mathematical models into the form of several equations (KA1)

- Designing and make decisions using mixed methods namely elimination-substitution (KE1)

- Making conclusions (KLP)

TABLE IX. TRIANGULATION RESUlTS HOTS 1 AND HOTS 2 SS TEST DATA COMPLETING PROBLEM NUMBER 2

\begin{tabular}{|l|l|}
\hline $\begin{array}{c}\text { Indicator } \\
\text { Codes }\end{array}$ & \multicolumn{1}{|c|}{ The Convergence Interpretation } \\
\hline KA1 & $\begin{array}{l}\text { Analyzing information by making mathematical } \\
\text { models into the form of several equations }\end{array}$ \\
\hline KE1 & $\begin{array}{l}\text { Designing and making decisions using mixed } \\
\text { methods, namely elimination-substitution method }\end{array}$ \\
\hline KLP & Making conclusions from the results obtained \\
\hline
\end{tabular}

a) SS data conclusions in solving HOTS questions: Based on the triangulation results, it can be concluded that SS's high-level thinking ability is only in three indicators in solving item number 2. In solving questions, SS used one method, namely the mixed method. The reason is that the SS are not accustomed to using other means and are wasting their time. There was no confidence in the SS to find the right answer. SS is aware of other methods that can be used in solving the problem, and SS can name both methods. Based on the results of the written test and interview data, it can be concluded that SS's high-order thinking skills solve question number 2 as follows:

- Analysing information by making mathematical models into the form of several equations. (KA1)

- Designing and making decisions using mixed methods, namely the elimination-substitution method (KE1)

- Making conclusions from the results obtained (KLP)

The following is the interpretation of the SR convergence on the HOTS 1 test and HOTS 2 test:

\section{b) HOTS 1 SS validation in solving problem number}

- SR data HOTS validation in problems solving: The validity of the SR data in solving question number 1 on the HOTS 1 test and HOTS 2 test, data triangulation was carried out to see the suitability of the data. It can be concluded that SR's high-order thinking ability in solving question number 1 is said to be valid. The following shows the triangulation results of the SR interview data in solving the questions

TABLE X. TRIANGULATION RESULTS OF TEST HOTS 1 AND HOTS 2 SR PROBLEM SOLVING NUMBER 1

\begin{tabular}{|l|l|}
\hline $\begin{array}{c}\text { Indicator } \\
\text { Codes }\end{array}$ & \multicolumn{1}{|c|}{ Abilities Used } \\
\hline KA1 & $\begin{array}{l}\text { Analyzing information by considering the } \\
\text { components contained in the problem into several } \\
\text { variables, namely } \mathrm{x}, \mathrm{y} \text { and } \mathrm{z} \text { (SRT104, SRT106) }\end{array}$ \\
\hline
\end{tabular}

- Withdrawing HOTS SR data conclusions in problem solving: Based on the triangulation results, it can be concluded that SR only uses one indicator of higher level thinking skills in question number 1 . SR also does not answer questions on the grounds that SR forgot about the method in solving the SPLTV material questions. SR honestly said that he needed to study SPLTV again in order to solve the problems given regarding the SPLTV material. Based on the results of written tests and interview data, it can be concluded that SR's higher order thinking ability in solving Three Variable Linear Equation System (SPLTV) questions number 1 is analyzing information by calculating the components in the questions into several variables (KA1). SR Data Validation in solving HOTS questions. The following tests the validity of the SR data in solving question number 2 on the HOTS 1 test and HOTS 2 test, by triangulating the data for the suitability of HOTS 1 and HOTS 2 data. SS data tends to be consistent, so it can be concluded that SR's higher order thinking skills in solving question number 2 is said to be valid. Table 19 results of triangulation of SR interview data in solving questions.

TABLE XI. TRIANGULATION RESULTS OF TEST HOTS 1 AND HOTS 2 SR PROBLEM SOLVING NUMBER 2

\begin{tabular}{|l|l|}
\hline $\begin{array}{c}\text { Indicator } \\
\text { Codes }\end{array}$ & \multicolumn{1}{|c|}{ The Convergence Interpretation } \\
\hline KA1 & $\begin{array}{l}\text { Analyzing information by considering several } \\
\text { components of the problem into several variables, } \\
\text { namely } \mathrm{x}, \mathrm{y} \text { and } \mathrm{z}\end{array}$ \\
\hline
\end{tabular}

8) Withdrawing HOTS SR data conclusions in problem solving: Based on the triangulation results, it can be concluded that SR only uses one indicator of high-order thinking skills in working on question number 2. SR only writes and explains what he knows without continuing to solve the problem. To be honest, SR forgot the method / method, and he said there were many and long ways. SR also admitted honestly that he could not work on the questions given. Based on the results of the written test data and interview transcripts, it was concluded that the SR's high-level thinking ability in solving the Three Variable Linear Equation System (SPLTV) question item number 2 was only on the indicator of analyzing information by taking the components in the question into several variables, namely $\mathrm{x}, \mathrm{y}$ and $\mathrm{z}$ (KA1).

It is clearer that the results of the analysis of the three students of high, medium and low ability can be recapitulated in Table 20 to make it easier to read the research data. 
TABLE XII. HIGH ORDER THINKING SKILL OF HIGH ABILITY (ST), Medium (SS), AND Low (SR) STUDENTS In PROBLEM SOLVING

\begin{tabular}{|c|c|c|}
\hline \multicolumn{3}{|c|}{$\begin{array}{c}\text { Indicators of Students' High Order Thinking Skills in Problems } \\
\text { Solving SPLTV }\end{array}$} \\
\hline$S T$ & $S S$ & $S R$ \\
\hline 1. Analysis skill & Analysis & 1. Analysis skill \\
\hline $\begin{array}{l}\text { Analyze information } \\
\text { by making } \\
\text { mathematical models } \\
\text { into tables and then } \\
\text { in the form of } \\
\text { mathematical } \\
\text { equations. (KA1) }\end{array}$ & $\begin{array}{l}\text { Analyze information } \\
\text { by making } \\
\text { mathematical models } \\
\text { into the form of } \\
\text { several equations. } \\
\text { (KA1) }\end{array}$ & $\begin{array}{l}\text { Analyze } \\
\text { information by } \\
\text { separating the } \\
\text { components in } \\
\text { the problem into } \\
\text { several } \\
\text { variables. (KA1) }\end{array}$ \\
\hline $\begin{array}{l}\text { Compares the values } \\
\text { of all the variables. } \\
\text { (KA2) }\end{array}$ & (KA2) & $(\mathrm{KA} 2)$ \\
\hline $\begin{array}{lr}\text { 2. Evaluation skill } \\
\text { Designing r and } \\
\text { making decisions } \\
\text { using r mixed } \\
\text { methods, namely } \\
\text { elimination- } \\
\text { substitution. (KE1) } \\
\text { Test the correctness } \\
\text { of the results } \\
\text { obtained r by } \\
\text { substituting the } \\
\text { values obtained into } \\
\text { known equations. } \\
\text { (KE2) }\end{array}$ & $\begin{array}{l}\text { 2. Evaluation skill } \\
\text { Designing and making } \\
\text { decisions using mixed } \\
\text { methods, namely } \\
\text { elimination- } \\
\text { substitution. } \\
\text { (NUMBER 1) } \\
\text { (KE2) }\end{array}$ & $\begin{array}{c}\text { Evaluation skill } \\
\text { (KE1) }\end{array}$ \\
\hline $\begin{array}{l}\text { 3. Creative skill } \\
\text { (KK) }\end{array}$ & $\begin{array}{l}\text { 3. Creative skill } \\
\text { (KK) }\end{array}$ & $\begin{array}{l}\text { 3. Creative skill } \\
\text { (KK) }\end{array}$ \\
\hline $\begin{array}{l}\text { 4. Logic and } \\
\text { Reasoning skill } \\
\text { Making conclusions } \\
\text { from the results } \\
\text { obtained. (KLP) }\end{array}$ & $\begin{array}{l}\text { 4. Logic and } \\
\text { Reasoning skill } \\
\text { Making conclusions } \\
\text { from the results } \\
\text { obtained. (KLP) }\end{array}$ & $\begin{array}{l}\text { 4. Logic and } \\
\text { Reasoning skill } \\
\text { (KLP) }\end{array}$ \\
\hline
\end{tabular}

\section{B. Discussion}

1) Higher order thinking skills of high ability students (ST) in problem solving SPLTV: In solving this Three Variable Linear Equation System (SPLTV) problem, ST uses three abilities including (1) Analytical Ability consisting of KA1 and KA2, (2) Ability to Evaluate which consists of KE1 and KE2 and (3) Logic and Reasoning Ability ( KLP). In applying the Analytical Ability, ST can analyze information by making mathematical models into tables and then proceed into the form of mathematical equations (KA1). Then to apply (KA2), ST compares the values of all the variables in this context the variables in question are variables a, b and c. Furthermore, in applying the Evaluation Capability, ST can design and make decisions using the mixed method, namely the eliminationsubstitution method (KE1). Next in applying (KE2), ST tests the correctness of the results obtained by substituting the values obtained into known equations. Finally, in using Logic and Reasoning Ability (KLP), ST makes conclusions from the results he obtained.

ST uses almost all higher-order thinking skills in solving SPLTV questions, only one ability that ST does not use is creative ability (KK). However, in solving the questions ST is very thorough because ST checks back on the answers he gets and ST is also able to explain how he answers the questions properly and regularly.

2) Higher order thinking skills of students with medium ability (SS) in solving SPLTV questions: In solving this Three Variable Linear Equation System (SPLTV) problem, SS also uses three capabilities including (1) Analysis Ability consisting of KA1 and SS not applying KA2, (2) Ability Evaluation consisting of KE1 and SS also not applying KE2, (3) Logic and Reasoning Ability (KLP). In using SS Analysis Skills can analyze information by making mathematical models into the form of several equations (KA1). Next, in applying the Evaluation Capability, SS can design and make decisions using the mixed method, namely the eliminationsubstitution method (KE1). Then in using the Logic and Reasoning Ability (KLP), SS makes a conclusion from the results that have been obtained.

Just like ST, SS also does not apply creative abilities. The difference between the two is that SS is not more precise than $\mathrm{ST}$, this can be seen from the way SS solves the problem, where SS does not re-test the correctness of the results it has obtained (KE2) and SS also does not compare the value of each variable (KA2). However, ST is also quite good at explaining the procedure for working on the SPLTV questions given.

3) Higher order thinking skills of students with medium ability (SR) in problem solving SPLTV: In solving this Three Variable Linear Equation System (SPLTV) problem, SR only applies one high-order thinking skill, namely (1) Analytical Ability consisting of KA1 and SR also does not apply KA2 in solving SPLTV questions. When using SR Analysis Ability, you can only analyze information by sorting the components in the question into a few variables (KA1). SR also has not been able to analyze information by making it into several equations. In fact, SR did not solve the problem on the grounds that the SPLTV material was not the material he liked, then this material also had many methods or methods that could be used so that he forgot, and SR also admitted that he had not repeated this material for a long time. However, SR knows that the questions given are questions with SPLTV material and SR also knows that there are many ways or methods that can be used in problem solving SPLTV .

\section{CONCLUSION}

Based on the results of the study, it can be concluded that high-ability students can use three indicators of high-order thinking skill, namely analytical skill, evaluation skill, and logical and reasoning skills in problems solving SPLTV. 
Students with moderate abilities can also use three indicators of high-order thinking skill, namely analytical skills, evaluation skills, and logical and reasoning skills in solving SPLTV problems. However, low-ability students only apply one highorder thinking skill, namely the analytical skill to problems solve SPLTV. It is suggested that future research continue to train students' Higher Order Thinking Skills from the profile that each high, medium, and low-ability student has

\section{REFERENCES}

[1] H. Retnawati, J. Arlinwibowo, N.F. Wulandari, and R.G. Pradani, "Teachers' difficulties and strategies in physics teaching and learning that applying mathematics," Journal of Baltic Science Education, vol. 17 , pp. 120,2018

[2] A. Wijaya, M. van den Heuvel-Panhuizen, and M. Doorman, "Opportunity-to-learn context-based tasks provided by mathematics textbooks," Educational studies in Mathematics, vol. 89, pp. 41-65, 2015 .

[3] K. Kartianom, and H. Retnawati, "Why are their mathematical learning achievements different? Re-analysis timss 2015 data in Indonesia, Japan and Turkey," International Journal on New Trends in Education and Their Implications, vol. 9, pp. 33-46, 2018.

[4] T. Widodo and S. Kadarwati, "Higher order thinking berbasis pemecahan masalah untuk meningkatkan hasil belajar berorientasi pembentukan karakter siswa," Jurnal Cakrawala Pendidikan, vol. 5, 2013.

[5] A. Thomas and G. Thorne, "How to increase higher level thinking," The Center for Development \& Learning, 7, 2009.

[6] L.W. Anderson and D.R. Krathwohl, A taxonomy for learning, teaching, and assessing: A revision of Bloom's taxonomy of educational objectives. New York: Longman, 2001.

[7] W. Winarni, "Peningkatan Kemampuan Berpikir Tingkat Tinggi Menggunakan Huruf Kapital Melalui Penerapan Model PJBL di SDIT Izzatul Islam Getasan," Manajemen Pendidikan, vol. 14, pp. 18-24, 2019.

[8] T.C. Chun and M.N.L.Y.B. Abdullah, "The teaching of higher order thinking skills (HOTS) in Malaysian schools: Policy and practices," MOJEM: Malaysian Online Journal of Educational Management, vol. 7, pp. 1-18, 2019.

[9] S. Sugiyono, Metode Penelitian Kuantitatif, Kualitatif dan R\&D. Bandung: PT Alfabeta, 2016.

[10] J.R. Raco, Metode Penelitian Kualitatif: Jenis, Karakteristik dan Keunggulannya. Jakarta: Grasindo, 2018.

[11] L.J. Moleong, Metode Penelitian Kualitatif. Bandung: Remaja Rosdakarya, 2009. 